Д. В. Дабіжа, кандидат юридичних наук, заступник начальника відділу звітності Департаменту інбормаційно-аналітичної підтримки, Національна полічія України, МВС України, м. Київ ORCID: https://orcid.org/0000-0001-7330-4468

\title{
НОРМАТИВНО-ПРАВОВЕ ЗАБЕЗПЕЧЕННЯ ФУНКЦІОНУВАННЯ Й РОЗВИТКУ АВТОМАТИЗОВАНИХ ІНФОРМАЦІЙНИХ СИСТЕМ І ЇХ ПІДСИСТЕМ, ВИКОРИСТОВУВАНИХ ОРГАНАМИ (ПІДРОЗДІЛАМИ) ПОЛІЦІї
}

\begin{abstract}
Мета статті - на основі комплексного аналізу правового механізму забезпечення функціонування автоматизованих інформаційних систем та їх підсистем, можливостей використання облікової інформації, яка міститься в базах (банках) даних, що входять до єдиної інформаційної системи МВС, запропонувати напрями вдосконалення нормативно-правового забезпечення функціонування та розвитку автоматизованих інформаційних систем і підсистем, використовуваних органами (підрозділами) поліції. Методологія. Достовірність отриманих результатів і висновків забезпечено такими методами дослідження, як узагальнення - для формулювання висновків за результатами вивчення нормативно-правових актів, що регламентують функціонування та використання інформаційних систем і підсистем в органах (підрозділах) поліції; аналізу та синтезу - для визначення особливостей функціонування та використання інформаційних систем і підсистем в органах (підрозділах) поліції. Системний підхід дозволив окреслити основу правового забезпечення використання баз (банків) даних МВС України, зокрема й органами (підрозділами) поліції під час виявлення, розкриття і розслідування кримінальних правопорушень, провадження оперативно-розшукової діяльності. Наукова новизна. Для вдосконалення нормативно-правового забезпечення функціонування та розвитку автоматизованих інформаційних систем і підсистем, використовуваних органами (підрозділами) поліції, запропоновано запровадити єдиний нормативно-правовий акт із регламентації основ облікової діяльності всіх інформаційних систем та їх підсистем, які забезпечують наповнення й підтримання в актуальному стані інформаційних ресурсів МВС України; розробити та на законодавчому рівні закріпити методичні рекомендації щодо формування й практичного використання всіх інформаційних систем та їх підсистем, що функціонують в органах (підрозділах) поліції, з докладним описом особливостей цього процесу; перевести в законодавчу площину функціонування інформаційних систем і підсистем, регламентованих внутрішньою документацією (наказами організаційно-розпорядчого характеру, дорученнями, листами тощо), дані яких мають значення для кримінального провадження. Висновки. Системно опрацьовано правовий механізм забезпечення функціонування автоматизованих інформаційних систем та їх підсистем, використовуваних органами (підрозділами) поліції; визначено прогалини в нормативно-правовому забезпеченні функціонування та розвитку автоматизованих інформаційних систем і підсистем, використовуваних органами (підрозділами) поліції; запропоновано зміни правового механізму забезпечення функціонування автоматизованих інформаційних систем та їх підсистем, використовуваних органами (підрозділами) поліції.

Ключові слова: бази (банки) даних; обліки; автоматизовані інформаційні системи; автоматизовані інформаційні системи та їх підсистеми; інтегрована автоматизована система; правові підстави; розслідування кримінальних правопорушень; інформаційне забезпечення.
\end{abstract}

\section{Вступ}

Реформування системи МВС України зумовлює необхідність подальшого вдосконалення правового механізму забезпечення використання баз (банків) даних МВС України, зокрема й органами (підрозділами) поліції під час виявлення, розкриття та розслідування кримінальних правопорушень, провадження оперативно-розшукової діяльності.

Для комплексного правового забезпечення цієї діяльності та її гармонізації саме на рівні нормативно-правових актів мають запроваджуватися відповідні автоматизовані інформаційні системи, які забезпечують наповнення та підтримання в актуальному стані інформаційних ресурсів МВС України, визначають коло користувачів, які мають доступ до інформації, відповідальних за формування та ведення обліків, окреслюють питання, пов'язані з процесом використання таких систем і термінами зберігання інформації. Тому на часі вдосконалення нормативно-правового забезпечення функціонування та розвитку автоматизованих інформаційних систем та їх підсистем, започаткування нових підходів до підвищення 
ефективності використання баз (банків) даних МВС України органами (підрозділами) поліції.

Вагомий внесок у розроблення організаційно-правових засад використання обліків і автоматизованих інформаційних систем у правоохоронних органах зробили В. В. Бірюков, А. Е. Волкова, I. О. Ієрусалімов, Є. Д. Лук'янчиков, Н. І. Клименко, В. О. Полікарпов, Е. О. Разумов, М. В. Салтевський, М. Я. Сегай, Р. А. Усманов, В. Г. Хахановський, М. Я. Швець, В. Ю. Шепітько та ін.

На монографічному рівні досліджено, зокрема, такі питання: методологічні засади інформаційного забезпечення розслідування злочинів (Lukianchykov, 2005); теоретичні основи інформаційно-довідкового забезпечення розслідування злочинів (Biriukov, 2009); проблеми теоpiї i практики криміналістичної інформатики (Khakhanovskyi, 2010); система інформаційноаналітичного забезпечення правоохоронних органів в умовах електронного урядування (Yershov, Durdynets, Ishchenko, \& Khakhanovskyi, 2018); a також інформаційне забезпечення використання науково-технічних досягнень в розслідуванні злочинів (Iierusalimov, 1997); інформаційне забезпечення розкриття та розслідування злочинів (Belov, 2007); криміналістичні обліки при розслідуванні митних злочинів (Polikarpov, 2008); використання інформаційних систем в експертних підрозділах МВС України (Piliukov, 2009); інформаційно-довідкові криміналістичні обліки: теорія, організація, використання (Volkova, \& Razumov, 2013); використання обліків та автоматизованих інформаційних систем при розслідуванні кримінальних правопорушень (Dabizha, 2017);

Обліки та автоматизовані системи як інструментарій в інших сферах людської діяльності розглянуто в різних площинах, як-от: національні інформаційні процеси в умовах глобалізації (Horovyi, 2015); підхід щодо оцінювання надійності функціонування автоматизованої системи управління «Ореанда-ПС» (Medvediev, Kasianenko, \& Korenivska, 2018); інформаційні системи кримінального судочинства (Ioimo, 2018); обгрунтування показника якості системи інформаційної безпеки автоматизованої інформаційної системи органу військового управління (Krainov, \& Hrozovskyi, 2019); автоматизовані інформаційні системи підтримання прийняття управлінських рішень у галузі екологічної безпеки (Yatsyshyn, Popov, Artemchuk, Kovach, \& Zinovieva, 2019); система підтримання прийняття рішень для забезпечення інформаційної безпеки автоматизованих систем управління процесами (Kirillova, Vasilyev, Nikonov, \& Berkholts, 2019, Jan.); автоматизована система ідентифікації злочинців за допомогою відтворення обличчя (Karve, Balasubramanian, Chaudhari, \& Mane, 2020).
Крім того, вітчизняні дослідники останнім часом висловлювалися з питань використання автоматизованої інформаційної системи ідентифікації пальцевих відбитків в організації розкриття та розслідування злочинів (Kazhanov, 2016); функціонування дактилоскопічного обліку Експертної служби МВС України в розрізі взаємодії з правоохоронними органами інших країн (Temnyk, 2019); концептуальні засади інформаційно-аналітичного забезпечення криміналістичної діяльності; поняття, система та завдання інформаційно-аналітичного забезпечення криміналістичної діяльності; підвищення ефективності інформаційно-аналітичного забезпечення виявлення та розслідування злочинів, учинених із застосуванням вогнепальної зброї (Bondar, 2019a; 2019b; 2019c); щодо пріоритетних напрямів розробки сучасної системи криміналістичного обліку (Bukhonskyi, 2020).

А втім, попри вагомий науковий доробок, низка проблем, пов'язаних із нормативно-правовим забезпеченням функціонування та розвитку автоматизованих інформаційних систем, зокрема необхідністю запровадження єдиного нормативного акта 3 регламентації основ облікової діяльності всіх інформаційних систем правоохоронних органів із внесенням відповідних змін до законодавства України (Volkova, \& Razumov, 2013, s. 69-73; Dabizha, 2017, s. 12-13), оскільки на рівні нормативних актів (наказів) мають визначатися загальні вимоги щодо створення та функціонування інформаційних систем (Biriukov, 2009, s. 540-554), а також у контексті останніх нормотворчих ініціатив потребує додаткової уваги.

\section{Мета й завдання дослідження}

Мета статті - на основі комплексного аналізу правового механізму забезпечення функціонування автоматизованих інформаційних систем та ї підсистем, можливостей використання облікової інформації, яка міститься в базах (банках) даних, що входять до єдиної інформаційної системи Мiністерства внутрішніх справ України (далі - ЄIC $\mathrm{MBC}$ ), запропонувати напрями вдосконалення нормативно-правового забезпечення функціонування та розвитку автоматизованих інформаційних систем та їх підсистем, використовуваних органами (підрозділами) поліції.

Для досягнення цієї мети необхідно виконати такі завдання:

системно опрацювати правовий механізм забезпечення функціонування автоматизованих інформаційних систем та їх підсистем, використовуваних органами (підрозділами) поліції;

визначити прогалини в нормативно-правовому забезпеченні функціонування та розвитку автоматизованих інформаційних систем та їх під- 
систем, використовуваних органами (підрозділами) поліції;

запропонувати зміни правового механізму забезпечення функціонування автоматизованих інформаційних систем та їх підсистем, використовуваних органами (підрозділами) поліції.

\section{Виклад основного матеріалу}

Основою правового забезпечення функціонування автоматизованих інформаційних систем $€$ закони, які встановлюють загальнообов'язкові вимоги щодо необхідності й доцільності створення в органах державної влади облікової діяльності, необхідної для реалізації своїх цілей і завдань (in particular: Pro informatsiiu, 1992; Pro operatyvno-rozshukovu diialnist, 1992; Pro zakhyst informatsii $v$ informatsiino-telekomunikatsiinykh systemakh, 1994; Pro Natsionalnu prohramu informatyzatsii, 1998; Pro elektronni dokumenty ta elektronnyi dokumentoobih, 2003; Pro telekomunikatsii, 2003; Pro zakhyst personalnykh danykh, 2010; Pro dostup do publichnoi informatsii, 2011; Pro Natsionalnu politsiiu, 2015).

Загальні засади функціонування автоматизованих інформаційних систем передбачають підзаконні нормативно-правові акти (Pro zatverdzhennia Polozhennia pro Natsionalnu politsiiu: postanova Kabinetu Ministriv Ukrainy, 2015; Pro zatverdzhennia Polozhennia pro yedynu informatsiinu systemu Ministerstva vnutrishnikh sprav ta pereliku yii priorytetnykh informatsiinykh resursiv: postanova Kabinetu Ministriv Ukrainy, 2018).

Відомчі нормативно-правові акти регламентують особливості функціонування певних автоматизованих інформаційних систем та їх підсистем, які забезпечують наповнення та підтримання в актуальному стані відповідних обліків, окреслюючи мету, завдання, призначення, інформаційні ресурси, структуру та суб'єктів використання автоматизованої інформаційної системи або іiі підсистеми (Pro zatverdzhennia Polozhennia pro informatsiino-telekomunikatsiinu systemu «Informatsiinyi portal Natsionalnoi politsii Ukrainy»: nakaz MVS Ukrainy, 2017; Pro zatverdzhennia Polozhennia pro avtomatyzovanu informatsiinu systemu operatyvnoho pryznachennia yedynoi informatsiinoi systemy MVS: nakaz MVS Ukrainy, 2017; Pro zatverdzhennia Instruktsii $z$ formuvannia ta vedennia informatsiinoi pidsystemy «Harpun» informatsiino-telekomunikatsiinoi systemy "Informatsiinyi portal Natsionalnoi politsii Ukrainy»: nakaz MVS Ukrainy, 2018; Pro zatverdzhennia Instruktsii $z$ formuvannia ta vedennia informatsiinoi pidsystemy "Iedynyi oblik» informatsiino-telekomunikatsiinoi systemy "Informatsiinyi portal Natsionalnoi politsii Ukrainy»: nakaz MVS Ukrainy, 2019; Pro zatverdzhennia Instruktsii $z$ formuvannia ta vedennia informatsiinoi pidsystemy "Atrium» in- formatsiino-telekomunikatsiinoi systemy «Informatsiinyi portal Natsionalnoi politsii Ukrainy»: nakaz MVS Ukrainy, 2019; Pro zatverdzhennia Instruktsii z formuvannia ta vedennia informatsiinoi pidsystemy "SLID» informatsiino-telekomunikatsiinoi systemy "Informatsiinyi portal Natsionalnoi politsii Ukrainy»: nakaz MVS Ukrainy, 2020; Pro zatverdzhennia Instruktsii z formuvannia ta vedennia informatsiinoi pidsystemy "Dorozhno-transportna pryhoda" informatsiino-telekomunikatsiinoi systemy "Informatsiinyi portal Natsionalnoi politsii Ukrainy»: nakaz MVS Ukrainy, 2020).

Приміром, серед завдань інформаційно-телекомунікаційної системи «Інформаційний портал Національної поліції України» (далі - система «ППНП) - забезпечення наповнення та підтримання в актуальному стані інформаційних ресурсів баз (банків) даних, що входять до ЄIC MBC електронної взаємодії з МВС та іншими органами державної влади. Призначення - оброблення інформації, яка є результатом діяльності поліції. Суб'єкти системи «ІПНП» - розпорядник, адміністратор, користувачі системи (Pro zatverdzhennia Polozhennia pro informatsiino-telekomunikatsiinu systemu «Informatsiinyi portal Natsionalnoi politsii Ukrainy»: nakaz MVS Ukrainy, 2017).

За своєю суттю система «ПНП» $є$ інструментальним програмним засобом, який забезпечує інформаційно-аналітичну діяльність Національної поліції України, зокрема із формування баз (банків) даних, визначених ст. 26 Закону України «Про Національну поліцію», та надання доступу до інформації, яка формується та об’єднується в EIC MBC за певними ознаками.

Метою інформаційної підсистеми «Єдиний облік» системи «ІПНП» (далі - IП «ЄО» системи «ІПНП») є, зокрема, забезпечення інформаційно-аналітичного підтримання діяльності поліції, спрямованого на запобігання правопорушенням та їх розкриття, встановлення зв'язків між даними, що мають значення для кримінального провадження. Структуру та зміст інформації об’єктів обліку в ІП «ЄО» системи «ІПНП» упорядковано за категоріями:

заяви та повідомлення про кримінальні правопорушення й інші події (дата, година та реєстраційний номер, зміст заяви чи повідомлення, вид та опис події, місце події, у тому числі GPS-координати, результат розгляду тощо);

учасники кримінального правопорушення чи іншої події (прізвище, ім’я, по батькові заявника, дата і місце народження, контактний номер телефону, дані про підозрюваних осіб: опис зовнішності, особливі прикмети й фотозображення та ін.);

речі, документи та майно, пов'язані з вчиненням правопорушення чи іншою подією (марка (модель) або модифікація, індивідуальний номер, 
колір, тип, серія, калібр, рік випуску, IMEI мобільного обладнання, номер і дата висновку експерта (експертного дослідження) зброї, реєстраційний номер, вид, марка, модель, колір, рік випуску, найменування та номери агрегатів транспортних засобів (Т3), серія та/або номер документа, дата видачі, орган, який видав, термін дії документа, індивідуальні особливості речі або майна, фотозображення тощо). Крім того, окреслено підстави для внесення уповноваженими посадовими особами органів (підрозділів) поліції інформації до IП «ЄО» системи «ІПНП» і терміни ії зберігання (Pro zatverdzhennia Instruktsii $z$ formuvannia ta vedennia informatsiinoi pidsystemy "Iedynyi oblik» informatsiino-telekomunikatsiinoi systemy "Informatsiinyi portal Natsionalnoi politsii Ukrainy»: nakaz MVS Ukrainy, 2019).

Завдяки розмежуванню структури та змісту інформації - об’єктів обліку ІП «ЄО» системи «ППНП» розв’язує завдання з пошуку інформації, що міститься в інформаційних підсистемах «Антикваріат», «Викрадені (втрачені) документи», «Єдиний облік», «Кримінальна зброя», «Річ» Інтегрованої інформаційно-пошукової системи МВС України (далі - IIПC) (Khakhanovskyi, Dabizha, \& Piaskovskyi, 2017, s. 10-11). Тобто IП «ЄО» системи «ІПНП» як своєрідний конгломерат є фундаментом для об'єднання даних у системі «ІПНП» (про кримінальні правопорушення та інші події, що надійшли від фізичних або юридичних осіб, про речі, документи та майно, пов'язані з їх вчиненням) в єдиний інформаційний простір та їх упорядкування.

Інформаційною підсистемою «Гарпун» системи «ІПНП» об'єднано інформацію про розшук транспортних засобів та номерних знаків, забезпечення оперативного реагування, моніторинг тимчасових потоків даних про номерні знаки, що надходять із систем відеофіксації, на предмет їх розшуку, одночасного перебування на різних Т3 (номерні знаки - двійники), використання номерних знаків, що, за даними Єдиного державного реєстру транспортних засобів Міністерства внутрішніх справ України, знищено, а також забезпечення взаємодії з державними та приватними виконавцями під час розшуку Т3 боржника у виконавчому провадженні. Облік об'єктів в ІП «Гарпун» системи «ІПНП» здійснюється за такими категоріями:

орієнтування про незаконне заволодіння Т3;

орієнтування про залишення Т3 місця дорожньо-транспортної пригоди;

орієнтування про залишення Т3 місця вчинення іншого правопорушення;

орієнтування оперативне про Т3;

евакуйовані Т3; розшук Т3 у зв'язку із незаконним заволодінням;

розшук Т3, що залишив місце дорожньо-транспортної пригоди;

розшук Т3 за іншими кримінальними правопорушеннями;

розшук Т3 боржника державним виконавцем;

розшук Т3 боржника приватним виконавцем;

розшук викраденого номерного знака;

розшук втраченого номерного знака;

знищені номерні знаки (Pro zatverdzhennia Instruktsii $z$ formuvannia ta vedennia informatsiinoi pidsystemy «Harpun» informatsiino-telekomunikatsiinoi systemy «Informatsiinyi portal Natsionalnoi politsii Ukrainy»: nakaz MVS Ukrainy, 2018).

Як свідчить цей перелік, ІП «Гарпун» системи «ІПНП» фактично поєднала відомості двох інформаційних систем: інформаційної підсистеми «Угон» ІІПС (Khakhanovskyi, Dabizha, \& Piaskovskyi, 2017, s. 11) та автоматизованої інформаційно-пошукової системи відеофіксації номерних знаків транспортних засобів «ВІДЕОКОНТРОЛЬ-Рубіж».

Метою інформаційної підсистеми «Дорожньо-транспортна пригода» системи «ІПНП» (далі ІП «ДТП» системи «ІПНП») є автоматизація процесів оброблення органами (підрозділами) поліції інформації про дорожньо-транспортні пригоди, забезпечення проведення оцінювання стану аварійності, аналізування обставин, причин і умов, що сприяли виникненню ДТП, прийняття управлінських рішень посадовими особами в межах компетенції поліції із запобігання ДТП, зменшення тяжкості їх наслідків, а також формування звітності про ДТП та забезпечення автоматизованого формування відповідного обліку ДТП.

Інформаційний ресурс ІП «ДТП» системи «ІПНП» становить інформація, здобута в межах компетенції органами (підрозділами) поліції, про ДТП відповідно до кодів, що містяться в системі «ППНП», а саме:

про реєстрацію ДТП;

характеристику місця ДТП (дорожні умови та дорожню обстановку);

учасників, потерпілих, травмованих та загиблих (прізвище, ім'я, по батькові (за наявності); дата народження (число, місяць, рік); громадянство; стать; місце народження; місце проживання (перебування); документ, що посвідчує особу);

транспортні засоби та їх страхування.

Ці ресурси формують і підтримують в актуальному стані уповноважені посадові особи того органу (підрозділу) поліції, на території обслуговування якого сталася ДТП (Pro zatverdzhennia Instruktsii $z$ formuvannia ta vedennia informatsiinoi pidsystemy «Dorozhno-transportna pryhoda» infor- 
matsiino-telekomunikatsiinoi systemy «Informatsiinyi portal Natsionalnoi politsii Ukrainy»: nakaz MVS Ukrainy, 2020).

Основними завданнями автоматизованої інформаційної системи оперативного призначення ЄIC МBC (далі - AIC ОП) є протидія злочинності та профілактична робота, спрямована на запобігання вчиненню правопорушень, об'єднання отриманої інформації та підвищення рівня інформаційно-аналітичного забезпечення оперативно-розшукової діяльності Національної поліції України.

До функцій AIC ОП належать:

автоматизація процесів обліку отриманої в процесі оперативно-розшукової діяльності Національної поліції України інформації;

збирання, зберігання, пошук та узагальнення інформації;

відображення повнотекстової, графічної, табличної і статистичної інформації, а також фото- й відеозображень;

утворення електронного досьє;

формалізація технологічних процесів оброблення інформації, визначення типових маршрутних технологічних схем для їх виконання;

забезпечення надійного зберігання інформаційних обліків та їх систематизація;

забезпечення комплексного захисту інформації та розмежування доступу до інформації, що зберігається в АIC ОП.

Обліку в АIC ОП підлягають відомості про осіб, щодо яких заведено оперативно-розшукові справи, отримані від осіб, які конфіденційно співробітничають 3 оперативними підрозділами Національної поліції України, а також під час оперативно-розшукових заходів у межах оперативно-розшукових справ. 3 огляду на специфіку обсяг, структура, порядок формування та використання інформаційних ресурсів АIC ОП визначаються окремими нормативно-правовими актами MBC (Pro zatverdzhennia Polozhennia pro avtomatyzovanu informatsiinu systemu operatyvnoho pryznachennia yedynoi informatsiinoi systemy MVS: nakaz MVS Ukrainy, 2017).

Інформаційну підсистему «Атріум» системи «ІПНП» (далі - ІП «Атріум» системи «ІПНП») створено 3 метою формування та наповнення електронного журналу контролю за прибуттям та взяття на облік раніше судимих осіб за формою, визначеною додатком до Порядку взаємодії установ виконання покарань, уповноважених органів із питань пробації та суб'єктів соціального патронажу під час підготовки до звільнення осіб, які відбувають покарання у вигляді обмеження волі або позбавлення волі на певний строк, затвердженого наказом Міністерства соціальної політики України,
Міністерства охорони здоров’я України, Міністерства внутрішніх справ України від 3 квітня 2018 р. № 974/5/467/609/280, контролю за поведінкою осіб, щодо яких встановлено адміністративний нагляд, а також інформаційно-аналітичного забезпечення діяльності поліції, у тому числі з використанням геоінформаційних підсистем для візуалізації інформації у вигляді електронних карт, коли аналізують і встановлюють зв'язки між даними, що мають значення під час розслідування кримінальних правопорушень, установлення місцезнаходження осіб, щодо яких встановлено адміністративний нагляд та які ухиляються від обліку.

Основне призначення ІП «Атріум» системи «ІПНП» - оброблення унесених відомостей, забезпечення вжиття профілактичних заходів спостереження і контролю за поведінкою окремих осіб, щодо яких установлено адміністративний нагляд, за прибуттям осіб, звільнених із місць позбавлення волі, до обраного ними місця проживання (Pro zatverdzhennia Instruktsii $z$ formuvannia ta vedennia informatsiinoi pidsystemy "Atrium» informatsiino-telekomunikatsiinoi systemy "Informatsiinyi portal Natsionalnoi politsii Ukrainy»: nakaz MVS Ukrainy, 2019).

Метою інформаційної підсистеми «СЛІД» системи «ІПНП» (далі - IП «СЛІД» системи «ІПНП») $е:$

облік інформації про об’єкти, вилучені під час проведення слідчих (розшукових) дій, у єдиному інформаційному просторі з використанням сучасних інформаційних технологій, комп’ютерного й телекомунікаційного обладнання;

забезпечення інформаційно-аналітичного підтримання діяльності органів (підрозділів) поліції, спрямованого на запобігання кримінальним правопорушенням та їх розкриття;

установлення зв'язків між даними, що мають значення для кримінального провадження; забезпечення оброблення інформації про об’єкти, вилучені під час проведення слідчих (розшукових) дій, наповнення та підтримання в актуальному стані інформаційних ресурсів баз (банків) даних, що входять до системи «ІПНП».

До ІП «СЛІД» системи «ІПНП» інформацію про об'єкти, вилучені під час проведення слідчих (розшукових) дій, вносять відповідальні особи органів досудового розслідування поліції (інспектори-криміналісти, яких залучають у встановленому законодавством порядку до проведення таких дій як спеціалістів) після того, як керівник (особа, яка виконує його обов'язки) підрозділу криміналістичного забезпечення органу досудового розслідування поліції оцінить ії на предмет наявності комплексу ідентифікаційних ознак.

За повноту інформації і своєчасність ії внесення (24 години 3 часу завершення відповідної 
слідчої (розшукової) дії; невідкладно - за фактом умисного вбивства або тяжкого тілесного ушкодження зі смертельними наслідками, вчинених в умовах неочевидності, або з обставинами, що обтяжують покарання, чи інших кримінальних правопорушень проти особи, які можуть викликати суспільний резонанс) відповідає інспектор-криміналіст.

Контроль за своєчасністю формування та ведення ІП «СЛІД», повнотою та достовірністю внесеної інформації здійснює керівник підрозділу криміналістичного забезпечення органу досудового розслідування.

Облік об'єктів в ІП «СЛІД» системи «ІПНП» ведеться за такими категоріями:

фотозображення слідів рук;

фотозображення слідів підошов взуття;

фотозображення слідів знарядь зламу;

фотозображення слідів структури матеріалу (рукавичок);

фотозображення слідів протекторів шин транспортних засобів;

мультимедійна інформація (фото-, відео-, звукозапис) щодо осіб, причетних до вчинення кримінального правопорушення;

мультимедійна інформація (фото-, відеозапис) обстановки події, що сталася;

інформація про кулі, гільзи і патрони зі слідами зброї;

інформація про об'єкти біологічного походження;

інформація про інші вилучені матеріальні об'єкти, які були знаряддям вчинення кримінального правопорушення та зберегли на собі його сліди або містять інші відомості, які можуть бути використані як доказ факту чи обставин, що встановлюються під час кримінального провадження (Pro zatverdzhennia Instruktsii $z$ formuvannia ta vedennia informatsiinoi pidsystemy «SLID» informatsiino-telekomunikatsiinoi systemy «Informatsiinyi portal Natsionalnoi politsii Ukrainy»: nakaz MVS Ukrainy, 2020).

Отже, сьогодні, коли інформація перетворилася на чи не найважливіший ресурс, а обліки та автоматизовані інформаційні системи стали необхідним інструментарієм майже в усіх сферах людської діяльності, зокрема й під час розслідування кримінальних правопорушень (Khakhanovskyi, Dabizha, \& Piaskovskyi, 2017, s. 4), чинний правовий механізм надає можливість використовувати, оновлювати й коригувати облікову інформацію, яка міститься в базах (банках) даних, що входять до ЄIC MBC, а також створює умови дотримання основних принципів інформаційно-довідкового забезпечення розслідування кримінальних правопорушень - законності, своєчасності, ефектив- ності, безперервності й захищеності інформації (Belov, 2007, s. 15). Безперервний ланцюг нормативних актів, наголошує В. В. Бірюков, робить певну категорію обліків ефективною. Саме докладна регламентація створення та функціонування певного обліку започатковує умови достовірності, відносності, можливості перевіряти інформацію, яка вміщується до певної інформаційної системи (Biriukov, 2009, s. 549-550).

Тому наразі постає питання подальшого вдосконалення нормативно-правового забезпечення функціонування автоматизованих інформаційних систем і підсистем, використовуваних органами (підрозділами) поліції, та їх розвитку. Для цього, убачається, доцільно на законодавчому рівні запровадити єдиний нормативно-правовий акт із регламентації основ облікової діяльності всіх інформаційних систем та їх підсистем, які забезпечують наповнення та підтримання в актуальному стані інформаційних ресурсів МBC України, на рівні відомчих нормативно-правових актів закріпити та впровадити методичні рекомендації щодо формування та використання всіх інформаційних систем і підсистем, які функціонують в органах (підрозділах) поліції, $з$ деталізацією особливостей їх використання, a також передбачити переведення в законодавчу площину функціонування інформаційних систем і підсистем, регламентованих внутрішньою документацією (наказами організаційно-розпорядчого характеру, дорученнями, листами тощо), дані яких мають значення для кримінального провадження.

\section{Наукова новизна}

Для вдосконалення нормативно-правового забезпечення функціонування та розвитку автоматизованих інформаційних систем і підсистем, використовуваних органами (підрозділами) поліції, запропоновано запровадити єдиний нормативно-правовий акт із регламентації основ облікової діяльності всіх інформаційних систем та ї підсистем, які забезпечують наповнення й підтримання в актуальному стані інформаційних ресурсів МВС України; розробити та на законодавчому рівні закріпити методичні рекомендації щодо формування й використання всіх інформаційних систем та їх підсистем, що функціонують в органах (підрозділах) поліції, з докладним описом особливостей цього процесу; перевести в законодавчу площину функціонування інформаційних систем і підсистем, регламентованих внутрішньою документацією (наказами організаційно-розпорядчого характеру, дорученнями, листами тощо), дані яких мають значення для кримінального провадження. 


\section{Висновки}

1. Правовий механізм забезпечення функціонування автоматизованих інформаційних систем та їх підсистем, використовуваних органами (підрозділами) поліції, що являє собою систему правових засобів, за допомогою яких упорядковано суспільні відносини відповідно до цілей і завдань правової держави, сьогодні перебуває у стані розвитку.

2. Нормативно-правове забезпечення функціонування автоматизованих інформаційних систем та їх підсистем, використовуваних органами (підрозділами) поліції, потребує вдосконалення, а також узгодження і гармонізації в межах системи законодавства і у взаємозв'язку з міжнародним правом, зокрема щодо неухильного дотримання Конституції України та законів України, Конвенції про захист прав людини і основоположних свобод, практики Європейського суду з прав людини та загальновизнаних принципів і норм міжнародного права.
3. Запропоновані зміни правового механізму забезпечення функціонування автоматизованих інформаційних систем та їх підсистем, використовуваних органами (підрозділами) поліціі, передбачають запровадження єдиного нормативно-правового акта з регламентації основ облікової діяльності всіх інформаційних систем і підсистем, які забезпечують наповнення й підтримання в актуальному стані інформаційних ресурсів МBC України; розроблення та закріплення на законодавчому рівні методичних рекомендацій щодо формування й використання всіх інформаційних систем та їх підсистем, що функціонують в органах (підрозділах) поліції, з докладним описом особливостей цього процесу; переведення в законодавчу площину функціонування інформаційних систем і підсистем, регламентованих внутрішньою документацією (наказами організаційно-розпорядчого характеру, дорученнями, листами тощо), дані яких мають значення для кримінального провадження.

\section{References}

Belov, O. A. (2007). Informacionnoe obespechenie raskrytiya i rassledovaniya prestuplenij. (Avtoref. dis. kand. yurid. nauk). Gosudarstvennoe obrazovatel'noe uchrezhdenie vysshego professional'nogo obrazovaniya «Moskovskaya gosudarstvennaya yuridicheskaya akademiya», M. 27 s. [in Russian].

Biriukov, V. V. (2009). Teoretychni osnovy informatsiino-dovidkovoho zabezpechennia rozsliduvannia zlochyniv: monohrafiia. Luhansk: RVV LDUVS im. Didorenka. 664 s. [in Ukrainan].

Bondar, V. S. (2019a). Kontseptualni zasady informatsiino-analitychnoho zabezpechennia kryminalistychnoi diialnosti. Visnyk Luhanskoho derzhavnoho universytetu vnutrishnikh sprav imeni E. O. Didorenka, 4 (88), $226-240$. [in Ukrainan]. DOI: https://doi.org/10.33766/2524-0323.88.226-240.

Bondar, V. S. (2019b). Poniattia, systema ta zavdannia informatsiino-analitychnoho zabezpechennia kryminalistychnoi diialnosti. Naukovyi visnykh Khersonskoho derzhavnoho universytetu, 2, 55-61 [in Ukrainan]. DOI: https://doi.org/10.32999/ksu2307-8049/2019-2-10.

Bondar, V. S. (2019c). Pidvyshchennia efektyvnosti informatsiino-analitychnoho zabezpechennia vyiavlennia ta rozsliduvannia zlochyniv, uchynenykh iz zastosuvanniam vohnepalnoi zbroi. Ekspert: paradyhmy yurydychnykh nauk $i$ derzhavnoho upravlinnia, 3 (5), 68-79 [in Ukrainan]. DOI: https://doi.org/10.32689/2617-9660-2019-3(5)-68-79.

Bukhonskyi, C. (2020). Shchodo priorytetnykh napriamiv rozrobky suchasnoi systemy kryminalistychnoho obliku. Visnyk Kyivskoho natsionalnoho universytetu imeni Tarasa Shevchenka. Viiskovo-spetsialni nauky, 2 (44), 36-39 [in Ukrainan]. DOI: https://doi.org/10.17721/1728-2217.2020.44.36-39.

Dabizha, D. V. (2017). Vykorystannia oblikiv ta avtomatyzovanykh informatsiinykh system pry rozsliduvanni kryminalnykh pravoporushen. (Avtoref. dys. kand. yuryd. nauk). Natsionalna akademiia vnutrishnikh sprav Ukrainy, Kyiv. 20 s. [in Ukrainan].

Horovyi, V. (2015). National information processes under globalization: Monograph. Kyiv: VNLU. 330 p. [in Ukrainan]. DOI: $10.15407 /$ nbuv.0002151.

Iierusalimov, I. O. (1997). Informatsiine zabezpechennia vykorystannia naukovo-tekhnichnykh dosiahnen $v$ rozsliduvanni zlochyniv. (Dys. kand. yuryd. nauk). Natsionalna akademiia vnutrishnikh sprav Ukrainy, Kyiv. 167 s. [in Ukrainan].

Ioimo, R. (2018). Introduction to Criminal Justice Information Systems. New York. 357 p. DOI: https://doi.org/10.4324/9781315368504.

Karve, A., Balasubramanian, M., Chaudhari, K., \& Mane, S. B. (2020). Automated Criminal Identification System Using Face Generation. In: Pandian, A., Ntalianis, K., Palanisamy, R. (Eds.). Intelligent Computing, Information and Control Systems. ICICCS 2019. Advances in Intelligent Systems and Computing, vol. 1039. Springer, Cham. DOI: https://doi.org/10.1007/978-3-030-30465-2_63.

Kazhanov, S. P. (2016). Vykorystannia avtomatyzovanoi informatsiinoi systemy identyfikatsii paltsevykh vidbytkiv $v$ orhanizatsii rozkryttia ta rozsliduvannia zlochyniv. Kyiv. $104 \mathrm{~s}$. [in Ukrainan].

Khakhanovskyi, V. H. (2010). Problemy teorii i praktyky kryminalistychnoi informatyky: monohrafiia. Kyiv: Vyd. Dim «Avanpost-Prym». 382 s. [in Ukrainan]. 
Khakhanovskyi, V. H., Dabizha, D. V., \& Piaskovskyi, V. V. (2017). Osoblyvosti vykorystannia oblikiv ta avtomatyzovanykh informatsiinykh system pry rozsliduvanni kryminalnykh pravoporushen: metodychni rekomendatsii. Kyiv: NAVS. 37 s. [in Ukrainan].

Kirillova, A. D., Vasilyev, V. I., Nikonov, A. V., \& Berkholts, V. V. (2019, Jan). Decision support system in the task of ensuring information security of automated process control systems. Information Technology and Nanotechnology. DOI: $10.18287 / 1613-0073-2019-2416-477-486$.

Krainov, V. O., \& Hrozovskyi, R. I. (2019). Obgruntuvannia pokaznyka yakosti systemy informatsiinoi bezpeky avtomatyzovanoi informatsiinoi systemy orhanu viiskovoho upravlinnia. Suchasni informatsiini tekhnolohii u sferi bezpeky ta oborony, 2 (35), 111-114 [in Ukrainan].

DOI: 10.33099/2311-7249/2019-34-1-111-114.

Lukianchykov, Ye. D. (2005). Metodolohichni zasady informatsiinoho zabezpechennia rozsliduvannia zlochyniv: monohrafiia. Kyiv: NAVSU. 360 s. [in Ukrainan].

Medvediev, V. K., Kasianenko, M. V., \& Korenivska, I. S. (2018). Pidkhid shchodo otsiniuvannia nadiinosti funktsionuvannia avtomatyzovanoi systemy upravlinnia «Oreanda-PS». Suchasni informatsiini tekhnolohii u sferi bezpeky ta oborony, 3 (33), 81-86 [in Ukrainan].

DOI: https://doi.org/10.33099/2311-7249/2018-33-3-81-86.

Piliukov, Yu. O. (2009). Vykorystannia informatsiinykh system v ekspertnykh pidrozdilakh MVS Ukrainy. (Avtoref. dys. kand. yuryd. nauk). Kyivskyi natsionalnyi universytet vnutrishnikh sprav, Kyiv. 22 s. [in Ukrainan].

Polikarpov, V. A. (2008). Kriminalisticheskie uchety pri rassledovanii tamozhennyh prestuplenij. (Avtoref. dis. kand. yurid. nauk). Gosudarstvennoe obrazovatel'noe uchrezhdenie vysshego professional'nogo obrazovaniya «Rossijskaya tamozhennaya akademiya», M. 28 s. [in Russian].

Pro dostup do publichnoi informatsii: Zakon Ukrainy № 2939-VI. (2011). Uziato z https://zakon.rada.gov.ua/laws/ show/2939-17 [in Ukrainan].

Pro elektronni dokumenty ta elektronnyi dokumentoobih: Zakon Ukrainy № 851-IV. (2003). Uziato z https://zakon.rada. gov.ua/laws/show/851-15 [in Ukrainan].

Pro informatsiiu: Zakon Ukrainy № 2657-XII. (1992). Uziato z https://zakon.rada.gov.ua/laws/show/2657-12 [in Ukrainan].

Pro Natsionalnu politsiiu: Zakon Ukrainy № 580-VIII. (2015). Uziato z https://zakon.rada.gov.ua/laws/show/580-19 [in Ukrainan].

Pro Natsionalnu prohramu informatyzatsii: Zakon Ukrainy № 74/98-VR. (1998). Uziato z https://zakon.rada.gov.ua/laws/ show/74/98-\%D0\%B2\%D1\%80 [in Ukrainan].

Pro operatyvno-rozshukovu diialnist: Zakon Ukrainy № 2135-XII. (1992). Uziato z https://zakon.rada.gov.ua/laws/ show/2135-12 [in Ukrainan].

Pro telekomunikatsii: Zakon Ukrainy № 1280-IV. (2003). Uziato z https://zakon4.rada.gov.ua/laws/show/1280-15 [in Ukrainan].

Pro zakhyst informatsii v informatsiino-telekomunikatsiinykh systemakh: Zakon Ukrainy № 80/94-VR. (1994). Uziato z https://zakon.rada.gov.ua/laws/show/80/94-\%D0\%B2\%D1\%80 [in Ukrainan].

Pro zakhyst personalnykh danykh: Zakon Ukrainy № 2297-VI. (2010). Uziato z https://zakon.rada.gov.ua/laws/show/229717 [in Ukrainan].

Pro zatverdzhennia Instruktsii z formuvannia ta vedennia informatsiinoi pidsystemy «Atrium» informatsiino-telekomunikatsiinoi systemy «Informatsiinyi portal Natsionalnoi politsii Ukrainy»: nakaz MVS Ukrainy № 1032. (2019). Uziato z https://zakon.rada.gov.ua/laws/show/z0217-20 [in Ukrainan].

Pro zatverdzhennia Instruktsii z formuvannia ta vedennia informatsiinoi pidsystemy «Dorozhno-transportna pryhoda» informatsiino-telekomunikatsiinoi systemy «Informatsiinyi portal Natsionalnoi politsii Ukrainy»: nakaz MVS Ukrainy № 533. (2020). Uziato z https://zakon.rada.gov.ua/laws/show/z0726-20\#Text [in Ukrainan].

Pro zatverdzhennia Instruktsii $\mathrm{z}$ formuvannia ta vedennia informatsiinoi pidsystemy «Harpun» informatsiino-telekomunikatsiinoi systemy «Informatsiinyi portal Natsionalnoi politsii Ukrainy»: nakaz MVS Ukrainy № 497. (2018). Uziato z https://zakon.rada.gov.ua/laws/show/z0787-18 [in Ukrainan].

Pro zatverdzhennia Instruktsii z formuvannia ta vedennia informatsiinoi pidsystemy «Iedynyi oblik» informatsiino-telekomunikatsiinoi systemy «Informatsiinyi portal Natsionalnoi politsii Ukrainy»: nakaz MVS Ukrainy № 508. (2019). Uziato z https://zakon.rada.gov.ua/laws/show/z0739-19\#Text [in Ukrainan].

Pro zatverdzhennia Instruktsii z formuvannia ta vedennia informatsiinoi pidsystemy «SLID» informatsiino-telekomunikatsiinoi systemy «Informatsiinyi portal Natsionalnoi politsii Ukrainy»: nakaz MVS Ukrainy № 257. (2020). Uziato z https://zakon.rada.gov.ua/laws/show/z0319-20 [in Ukrainan].

Pro zatverdzhennia Polozhennia pro avtomatyzovanu informatsiinu systemu operatyvnoho pryznachennia yedynoi informatsiinoi systemy MVS: nakaz MVS Ukrainy № 870. (2017). Uziato z https://zakon.rada.gov.ua/laws/show/z1433-17 [in Ukrainan].

Pro zatverdzhennia Polozhennia pro informatsiino-telekomunikatsiinu systemu «Informatsiinyi portal Natsionalnoi politsii Ukrainy»: nakaz MVS Ukrainy № 676. (2017). Uziato z http://zakon.rada.gov.ua/laws/show/z1059-17 [in Ukrainan].

Pro zatverdzhennia Polozhennia pro Natsionalnu politsiiu: postanova Kabinetu Ministriv Ukrainy № 877. (2015). Uziato z https://zakon.rada.gov.ua/laws/show/877-2015-\%D0\%BF [in Ukrainan].

Pro zatverdzhennia Polozhennia pro yedynu informatsiinu systemu Ministerstva vnutrishnikh sprav ta pereliku yii prio- 
rytetnykh informatsiinykh resursiv: postanova Kabinetu Ministriv Ukrainy № 1024. (2018). Uziato z https://zakon. rada.gov.ua/laws/show/1024-2018-\%D0\%BF [in Ukrainan].

Temnyk, I. M. (2019). Funktsionuvannia daktyloskopichnoho obliku Ekspertnoi sluzhby MVS Ukrainy v rozrizi vzaiemodii z pravookhoronnymy orhanamy inshykh krain [in Ukrainan].

DOI: http://doi.org/10.5281/zenodo.3376943.

Volkova, A. E., \& Razumov, E. A. (2013). Informacionno-spravochnye kriminalisticheskie uchety: teoriya, organizaciya, ispol'zovanie: monohrafiia. Sumy: Mriya. 342 s. [in Russian].

Yatsyshyn, A. V., Popov, O. O., Artemchuk, V. O., Kovach, V. O., \& Zinovieva, I. S. (2019). Avtomatyzovani informatsiini systemy pidtrymky pryiniattia upravlinskykh rishen u haluzi ekolohichnoi bezpeky. Informatsiini tekhnolohii i zasoby navchannia, 72 (4), 286-305.

DOI: https://doi.org/10.33407/itlt.v72i4.2993.

Yershov, S. V., Durdynets, V. V., Ishchenko, O. M., \& Khakhanovskyi, V. H. (2018). Systema informatsiino-analitychnoho zabezpechennia pravookhoronnykh orhaniv $v$ umovakh elektronnoho uriaduvannia. Kyiv. 352 s. [in Ukrainan].

\section{Список використаних джерел}

Белов, О. А. (2007). Информационное обеспечение раскрытия и расследования преступлений. (Автореф. дис. канд. юрид. наук). Государственное образовательное учреждение высшего профессионального образования «Московская государственная юридическая академия», М. 27 с.

Бірюков, В. В. (2009). Теоретичні основи інформаційно-довідкового забезпечення розслідування злочинів: монографія. Луганськ: РВВ ЛДУВС ім. Дідоренка. 664 с.

Бондар, В. С. (2019a). Концептуальні засади інформаційно-аналітичного забезпечення криміналістичної діяльності. Вісник Луганського державного університету внутрішніх справ імені Е. О. Дідоренка, 4 (88), 226-240. DOI: https://doi.org/10.33766/2524-0323.88.226-240.

Бондар, В. С. (2019b). Поняття, система та завдання інформаційно-аналітичного забезпечення криміналістичної діяльності. Науковий вісних Херсонського державного університету, 2, 55-61. DOI: https://doi.org/10.32999/ksu2307-8049/2019-2-10.

Бондар, В. С. (2019c). Підвищення ефективності інформаційно-аналітичного забезпечення виявлення та розслідування злочинів, учинених із застосуванням вогнепальної зброї. Експерт: парадигми юридичних наук $і$ державного управління, 3 (5), 68-79. DOI: https://doi.org/10.32689/2617-9660-2019-3(5)-68-79.

Бухонський, С. (2020). Щодо пріоритетних напрямів розробки сучасної системи криміналістичного обліку. Вісник Київського національного університету імені Тараса Шевченка. Військово-спеціальні науки, 2 (44), 36-39. DOI: https://doi.org/10.17721/1728-2217.2020.44.36-39.

Дабіжа, Д. В. (2017). Використання обліків та автоматизованих інбормаційних систем при розслідуванні кримінальних правопорущень. (Автореф. дис. канд. юрид. наук). Національна академія внутрішніх справ України, Київ. 20 c.

Horovyi, V. (2015). National information processes under globalization: Monograph. Kyiv: VNLU. 330 p. [in Ukrainan]. DOI: $10.15407 /$ nbuv.0002151.

Іерусалімов, I. О. (1997). Інформачійне забезпечення використання науково-технічних досягнень в розслідуванні злочинів. (Дис. канд. юрид. наук). Національна академія внутрішніх справ України, Київ. 167 с.

Ioimo, R. (2018). Introduction to Criminal Justice Information Systems. New York. 357 p. DOI: https://doi.org/10.4324/9781315368504.

Karve, A., Balasubramanian, M., Chaudhari, K., \& Mane, S. B. (2020) Automated Criminal Identification System Using Face Generation. In: Pandian, A., Ntalianis, K., Palanisamy, R. (Eds.). Intelligent Computing, Information and Control Systems. ICICCS 2019. Advances in Intelligent Systems and Computing, vol. 1039. Springer, Cham. DOI: https://doi.org/10.1007/978-3-030-30465-2_63.

Кажанов, С. П. (2016). Використання автоматизованої інформаційної системи ідентифікації пальиевих відбитків в організації розкриття та розслідування злочинів. Київ. $104 \mathrm{c}$.

Хахановський, В. Г. (2010). Проблеми теорії і практики криміналістичної інформатики: монографія. Київ: Вид. Дім «Аванпост-Прим». 382 с.

Хахановський, В. Г., Дабіжа, Д. В., \& Пясковський, В. В. (2017). Особливості використання обліків та автоматизованих інформаційних систем при розслідуванні кримінальних правопорушень: методичні рекомендації. Київ: HABC. 37 c.

Крайнов, В. О., \& Грозовський, Р. І. (2019). Обгрунтування показника якості системи інформаційної безпеки автоматизованої інформаційної системи органу військового управління. Сучасні інформаційні технології у сфері безпеки та оборони, 2 (35), 111-114.

DOI: $10.33099 / 2311-7249 / 2019-34-1-111-114$.

Kirillova, A. D., Vasilyev, V. I., Nikonov, A. V., \& Berkholts, V. V. (2019, Jan). Decision support system in the task of ensuring information security of automated process control systems. Information Technology and Nanotechnology.

DOI: $10.18287 / 1613-0073-2019-2416-477-486$.

Лук'янчиков, Є. Д. (2005). Методологічні засади інформачійного забезпечення розслідування злочинів: монографія. 
Київ: НАВСУ. 360 с.

Медведєв, В. К., Кас'яненко, М. В., \& Коренівська, І. С. (2018). Підхід щодо оцінювання надійності функціонування автоматизованої системи управління «Ореанда-ПС». Сучасні інбормаційні технології у сбері безпеки та оборони, 3 (33), 81-86.

DOI: https://doi.org/10.33099/2311-7249/2018-33-3-81-86.

Пілюков, Ю. О. (2009). Використання інформаційних систем в експертних підрозділах МвС Украйни. (Автореф. дис. канд. юрид. наук). Київський національний університет внутрішніх справ, Київ. 22 с.

Поликарпов, В. А. (2008). Криминалистические учеты при расследовании таможенных преступлений. (Автореф. дис. канд. юрид. наук). Государственное образовательное учреждение высшего профессионального образования «Российская таможенная академия», М. 28 с.

Про доступ до публічної інформації: Закон України № 2939-VI. (2011). Узято з https://zakon.rada.gov.ua/laws/ show/2939-17.

Про електронні документи та електронний документообіг: Закон України № 851-IV. (2003). Узято 3 https://zakon. rada.gov.ua/laws/show/851-15.

Про інформацію: Закон України № 2657-XII. (1992). Узято з https://zakon.rada.gov.ua/laws/show/2657-12.

Про Національну поліцію: Закон України № 580-VIII. (2015). Узято з https://zakon.rada.gov.ua/laws/show/580-19.

Про Національну програму інформатизації: Закон України № 74/98-BP. (1998). Узято з https://zakon.rada.gov.ua/ laws/show/74/98-\%D0\%B2\%D1\%80.

Про оперативно-розшукову діяльність: Закон України № 2135-XII. (1992). Узято з https://zakon.rada.gov.ua/laws/ show/2135-12.

Про телекомунікації: Закон України № 1280-IV. (2003). Узято з https://zakon4.rada.gov.ua/laws/show/1280-15.

Про захист інформації в інформаційно-телекомунікаційних системах: Закон України № 80/94-ВР. (1994). Узято 3 https://zakon.rada.gov.ua/laws/show/80/94-\%D0\%B2\%D1\%80.

Про захист персональних даних: Закон України № 2297-VI. (2010). Узято з https://zakon.rada.gov.ua/laws/show/2297-17.

Про затвердження Інструкції з формування та ведення інформаційної підсистеми «Атріум» інформаційно-телекомунікаційної системи «Інформаційний портал Національної поліції України»: наказ МВС України» № 1032. (2019). Узято з https://zakon.rada.gov.ua/laws/show/z0217-20.

Про затвердження Інструкції з формування та ведення інформаційної підсистеми «Дорожньо-транспортна пригода» інформаційно-телекомунікаційної системи «Інформаційний портал Національної поліції України»: наказ МВС України № 533. (2020). Узято з https://zakon.rada.gov.ua/laws/show/z0726-20\#Text.

Про затвердження Інструкції з формування та ведення інформаційної підсистеми «Гарпун» інформаційно-телекомунікаційної системи «Інформаційний портал Національної поліції України»: наказ МВС України № 497. (2018). Узято з https://zakon.rada.gov.ua/laws/show/z0787-18.

Про затвердження Інструкції з формування та ведення інформаційної підсистеми «Єдиний облік» інформаційно-телекомунікаційної системи «Інформаційний портал Національної поліції України»: наказ МВС України № 508. (2019). Узято з https://zakon.rada.gov.ua/laws/show/z0739-19\#Text.

Про затвердження Інструкції з формування та ведення інформаційної підсистеми «СЛІД» інформаційно-телекомунікаційної системи «Інформаційний портал Національної поліції України»: наказ МВС України № 257. (2020). Узято з https://zakon.rada.gov.ua/laws/show/z0319-20.

Про затвердження Положення про автоматизовану інформаційну систему оперативного призначення єдиної інформаційної системи МВС: наказ МВС України № 870. (2017). Узято з https://zakon.rada.gov.ua/laws/show/z1433-17.

Про затвердження Положення про інформаційно-телекомунікаційну систему «Інформаційний портал Національної поліції України»: наказ МВС України № 676. (2017). Узято з http://zakon.rada.gov.ua/laws/show/z1059-17.

Про затвердження Положення про Національну поліцію: постанова Кабінету Міністрів України № 877. (2015). Узято 3 https://zakon.rada.gov.ua/laws/show/877-2015-\%D0\%BF.

Про затвердження Положення про єдину інформаційну систему Міністерства внутрішніх справ та переліку іiі пріоритетних інформаційних ресурсів: постанова Кабінету Міністрів України № 1024. (2018). Узято 3 https:// zakon.rada.gov.ua/laws/show/1024-2018-\%D0\%BF.

Темник, І. М. (2019). Функціонування дактилоскопічного обліку Експертної служби МВС України в розрізі взаємодії з правоохоронними органами інших краӥн.

DOI: http://doi.org/10.5281/zenodo.3376943.

Волкова, А. Э., \& Разумов, Э. А. (2013). Информационно-справочные криминалистические учеть: теория, организация, использование: монография. Сумы: Мрія. 342 с.

Яцишин, А. В., Попов, О. О., Артемчук, В. О., Ковач, В. О., \& Зінов’єва, І. С. (2019). Автоматизовані інформаційні системи підтримки прийняття управлінських рішень у галузі екологічної безпеки. Інформаційні технології $i$ засоби навчання, 72 (4), 286-305.

DOI: https://doi.org/10.33407/itlt.v72i4.2993.

Єршов, С. В., Дурдинець, В. В., Іщенко, О. М., \& Хахановський, В. Г. (2018). Система інформаційно-аналітичного забезпечення правоохоронних органів в умовах електронного урядування. Київ. 352 с. 
D. Dabizha, Ph.D in Law,

Deputy Head of Reporting Department,

Department of Information and Analytical

Support of the National Police of Ukraine,

MIA of Ukraine, Kyiv, Ukraine

ORCID: https://orcid.org/0000-0001-7330-4468

\title{
REGULATORY AND LEGAL SUPPORT OF THE FUNCTIONING AND DEVELOPMENT OF AUTOMATED INFORMATION SYSTEMS AND THEIR SUBSYSTEMS USED BY POLICE BODIES (UNITS)
}

\begin{abstract}
The purpose of the paper: based on the comprehensive analysis of the legal framework ensuring the functioning of automated information systems and their subsystems, provisions for using the accounting information contained in data bases (banks) included in the single information system of the Ministry of Internal Affairs, to suggest ways to improve the regulatory and legal support of the functioning and development of the automated information systems and subsystems used by police bodies (units). Methodology. The reliability of the obtained results and conclusions is ensured by such research methods as generalization - to formulate conclusions based on the results of the study of laws and regulations governing the functioning and use of information systems and subsystems in police bodies (units); analysis and synthesis - to determine the special features of the functioning and use of information systems and subsystems in police bodies (units). The systematic approach made it possible to outline the basis of the legal support for the use of data bases (banks) of the Ministry of Internal Affairs of Ukraine, namely, by police bodies (units) during the etection, solving and investigation of criminal offences, criminal intelligence operations. Scientific novelty. In order to improve the regulatory and legal support of the functioning and development of automated information systems and subsystems used by police bodies (units), it is proposed to introduce a single regulatory legal act regulating the basics of accounting activities of all information systems and their subsystems, ensuring filling and updating of the information resources of the Ministry of Internal Affairs of Ukraine; to develop and enshrine at the statutory level the guidelines for the formation and practical use of all information systems and their subsystems functioning in police bodies (units), with the detailed description of special features of this process; to translate the functioning of information systems and subsystems regulated by internal documentation (organizational/management orders, instructions, letters, etc.), the data of which are important for criminal proceedings, into the statutory plane. Conclusions. The legal framework for ensuring the functioning of automated information systems and their subsystems used by police bodies (units) was systematically worked out; gaps in the regulatory and legal support of the functioning and development of automated information systems and subsystems used by police bodies (units) were identified; changes to the legal framework ensuring the functioning of automated information systems and their subsystems used by police bodies (units) were suggested.
\end{abstract}

Keywords: data bases (banks); accounts; automated information systems; automated information systems and their subsystems; integrated automated system; legal grounds; investigation of criminal offences; information support.

Д. В. Дабижа, кандидат юридических наук,

заместитель начальника отдела отчетности

Департамента информационно-аналитической

поддержки,

Национальная полищия Украины,

МВД Украины, г. Киев

ORCID: https://orcid.org/0000-0001-7330-4468

\section{НОРМАТИВНО-ПРАВОВОЕ ОБЕСПЕЧЕНИЕ ФУНКЦИОНИРОВАНИЯ И РАЗВИТИЯ АВТОМАТИЗИРОВАННЫХ ИНФОРМАЦИОННЫХ СИСТЕМ И ИХ ПОДСИСТЕМ, ИСПОЛЬЗУЕМЫХ ОРГАНАМИ (ПОДРАЗДЕЛЕНИЯМИ) ПОЛИЦИИ}

\footnotetext{
Цель статьи - на основе комплексного анализа правового механизма обеспечения функционирования автоматизированных информационных систем и их подсистем, возможностей использования учетной информации, содержащейся в базах (банках) данных, входящих в единую информационную систему МВД, предложить пути совершенствования нормативно-правового обеспечения функционирования и развития автоматизированных информационных систем и подсистем, используемых органами (подразделениями) полиции. Методология. Достоверность полученных результатов и выводов обеспечена такими методами
} 
исследования, как обобщение - для формулировки выводов по результатам изучения нормативно-правовых актов, регламентирующих функционирование и использование информационных систем и подсистем в органах (подразделениях) полиции; анализа и синтеза - для определения особенностей функционирования и использования информационных систем и подсистем в органах (подразделениях) полиции. Системный подход позволил определить основу правового обеспечения использования баз (банков) данных МВД Украины, в том числе органами (подразделениями) полиции при выявлении, раскрытии и расследовании уголовных правонарушений, в ходе оперативно-розыскной деятельности. Научная новизна. Для совершенствования нормативно-правового обеспечения функционирования и развития автоматизированных информационных систем и подсистем, используемых органами (подразделениями) полиции, предложено ввести единый нормативно-правовой акт, регламентирующий основы учетной деятельности всех информационных систем и их подсистем, которые обеспечивают наполнение и поддержку в актуальном состоянии информационных ресурсов МВД Украины; разработать и на законодательном уровне закрепить методические рекомендации по формированию и практическому использованию всех информационных систем и их подсистем, функционирующих в органах (подразделениях) полиции, с подробным описанием особенностей этого процесса; перевести в законодательную плоскость функционирование информационных систем и подсистем, регламентированных внутренней документацией (приказами организационно-распорядительного характера, поручениями, письмами и т. д.), данные которых имеют значение для уголовного производства. Bbıвды. Системно отработан правовой механизм обеспечения функционирования автоматизированных информационных систем и их подсистем, используемых органами (подразделениями) полиции; определены пробелы в нормативно-правовом обеспечении функционирования и развития автоматизированных информационных систем и подсистем, используемых органами (подразделениями) полиции; предложены изменения правового механизма обеспечения функционирования автоматизированных информационных систем и их подсистем, используемых органами (подразделениями) полиции.

Ключевые слова: базы (банки) данных; учет; автоматизированные информационные системы; автоматизированные информационные системы и их подсистемы; интегрированная автоматизированная система; правовые основания; расследование уголовных правонарушений; информационное обеспечение. 